\title{
MANAJEMEN TENAGA PENDIDIK DALAM MENINGKATKAN KOMPETENSI PROFESIONAL
}

\section{Ima Muslimatul Amanah}

Universitas Islam Negeri Sunan Gunung Djati Bandung Imamuslimatulamanah42@gmail.com

\section{A. Heris Hermawan}

Universitas Islam Negeri Sunan Gunung Djati Bandung herishermawan@uinsgd.ac.id

\section{Wahyu Hidayat}

Universitas Islam Negeri Sunan Gunung Djati Bandung wahyuhidayat@uinsgd.ac.id

\begin{abstract}
ABSTRAK
Pendidikan merupakan suatu proses pembinaan akal manusia yang mana potensi utamanya adalah sebagai makhluk yang berpikir. Pendidikan di dalamnya terdapat suatu proses pembelajaran yang keberhasilannya tergantung kepada sumber daya yang dinamakan tenaga pendidik atau guru. Oleh karenanya dalam suatu lembaga pendidikan perlu adanya proses manajemen tenaga pendidik yang baik guna meningkatkan kualitas pendidikan. Tujuan dalam penelitian ini yaitu untuk mengetahui bagaimana proses manajemen tenaga pendidik. Metode penelitian yang digunakan yaitu metode deskriptif dengan menggunakan pendekatan kualitatif. Teknik pengumpulan data yang digunakan yaitu teknik observasi, teknik wawancara baku terbuka, dan teknik studi dokumentasi. Hasil penelitian menunjukkan bahwa perencanaan tenaga pendidik di SMP IT Imam Bukhari dilakukan melalui beberapa tahapan yaitu tahap mapping, rekrutmen, seleksi dan penempatan. Pengorganisasian tenaga pendidik di SMP IT Imam Bukhari dilakukan dengan cara memberikan tugas tambahan selain mengajar, adapun pendistribusiannya dilakukan oleh pihak yayasan. Penyusunan staf di SMP IT Imam Bukhari di sesuaikan dengan kebutuhan dan mengacu pada standar pengelolaan sekolah. Penggerakkan tenaga pendidik di SMP IT Imam Bukhari dilakukan melalui beberapa program yaitu pembinaan spiritual, halaqah Qur'an, fiah qalilah, pelatihan, dan inovasi pembelajaran. Pengawasan yang dilakukan di SMP IT Imam Bukhari yaitu melalui pengecekan kehadiran oleh Kepala Sekolah baik kehadiran secara manual maupun finger print dan juga observasi lapangan pada proses belajar mengajar.
\end{abstract}

Kata kunci: Pendidikan, tenaga pendidik, kompetensi 


\begin{abstract}
Education is a process of fostering human reason where the main potential is as a thinking creature. Education in it there is a learning process whose success depends on resources called educators or teachers. Therefore in educational institution there needs to be a good management process for educators to improve the quality of education. The purpose of this research is to find out how the management process of educators. The research method used is descriptive method using a qualitative approach. Data collection techniques used were observation techniques, open standard interview techniques, and documentation study techniques. The results showed that the planning of teaching staff at Imam Bukhari IT Middle School was carried out through several stages, namely the mapping, recruitment, selection and placement stages. The organization of teaching staff at Imam Bukhari IT Middle School is carried out by giving additional duties besides teaching, while the distribution is carried out by the foundation. Staffing at Imam Bukhari IT Middle School is adjusted to the needs and refers to school management standards. Mobilizing the teaching staff at Imam Bukhari IT Middle School through several programs, namely spiritual guidance, halaqah Qur'an, fiah qalilah, training, and learning innovation. Supervision conducted at Imam Bukhari IT Middle School, namely through checking the attendance by the Principal, both manual and finger print attendance and also field observations on the teaching and learning process.
\end{abstract}

Key words: education, teacher, competence

\title{
PENDAHULUAN
}

Manajemen merupakan suatu proses dalam merencanakan, mengorganisir, mengarahkan, maupun mengendalikan kegiatan organisasi untuk mencapai tujuan melalui sumber daya organisasi (Hanafi dalam (Badrudin, 2015, p. 4)).

Pendidikan sebagai aktivitas berarti suatu upaya secara sadar yang dirancang untuk membantu seseorang maupun kelompok dalam mengembangkan ilmu pengetahuan, pandangan hidup, sikap dan keterampilan hidup baik yang bersifat individual atau sosial. Pendidikan tidak hanya dipandang sebagai sarana untuk mempersiapkan hidup yang akan datang namun juga untuk kehidupan sekarang yang dialami setiap individu dalam perkembangannya menuju tingkat kedewasaaan (Sagala, 2012, p. 1).

Pendidikan hakikatnya merupakan suatu proses pembinaan akal manusia yang merupakan potensi utama dari manusia sebagai makhluk berpikir. Dengan pembinaan olah pikir, manusia diharapkan semakin meningkatkan kecerdasannya dan meningkatkan pula kedewasaan berpikirnya terutama memiliki kecerdasan dalam memecahkan permasalahan dalam kehidupannya (Basri, 2009, p. 56).

Persoalan pendidikan saat ini diantaranya yaitu rendahnya mutu input, proses maupun output pendidikan. Komitmen masyarakat dan pemerintah yang belum sepenuhnya memadai untuk membangun pendidikan dan meningkatkan mutu sumber daya manusia, buku pelajaran yang silih berganti, kurikulum terlalu tinggi, otonomi daerah untuk sementara mencemaskan bagi kemajuan 
pendidikan, lemahnya kompetensi/profesional guru, daya masyarakat terhadap pendidikan masih lemah, jeritan guru non pegawai negeri sipil bergaji kecil dan pengawas, kolusi dalam rekrutmen calon guru, konflik antar komite sekolah dengan pihak sekolah, angka putus sekolah yang masih tinggi, dan lainnya. Permasalahan tersebut sangat berkaitan erat dengan manajemen pendidikan (Syarbini, 2012).

Untuk mewujudkan tercapainya tujuan pendidikan nasional diperlukan beberapa faktor pendukung yang sangat diperlukan dalam proses pencapaiannya, faktor-faktor tersebut meliputi sumber daya manusia, sarana dan prasarana, modal dan lain sebagainya. Namun, dari berbagai faktor tersebut, faktor yang paling penting dan sangat berpengaruh dalam berhasil atau tidaknya pendidikan adalah sumber daya manusia. Arus modernisasi dan teknologi yang berkembang semakin pesat menuntut tersedianya guru-guru yang semain berkualitas. Guru-guru yang berkualitas ini akan memberi pengaruh yang sangat positif bagi program pembelajaran (Susanti, 2014).

Tenaga pendidik menjadi salah satu komponen penting dalam pendidikan. Dalam UU No 14 Tahun 2005 tentang Guru dan Dosen Pasal 2 ayat 1 dijelaskan bahwa guru mempunyai kedudukan sebagai tenaga profesional pada jenjang pendidikan dasar, pendidikan menengah, dan pendidikan anak usia dini pada jalur pendidikan formal yang diangkat sesuai dengan peraturan perundangundangan. Guru profesional adalah guru yang mampu mengelola dirinya sendiri dalam melaksanakan tugas-tugasnya sehari-hari (Wahyudi, 2012). Profesionalisme yang dimaskud yaitu suatu proses yang bergerak dari ketidaktahuan menjadi tahu, dari ketidakmatangan menjadi matang (Fitriani et al., 2017).

Untuk mencapai profesionalitas tenaga pendidik atau guru tentunya haruslah memiliki kompetensi yang mumpuni. Sementara itu, standar kompetensi yang tertuang dalam Peraturan Menteri Pendidikan Nasional No. 16 Tahun 2007 tentang Standar Kualifikasi Akademik dan Kompetensi Guru dimana peraturan tersebut menyebutkan bahwa guru profesional harus memiliki empat kompetensi, yaitu kompetensi pedagogik, kompetensi kepribadian, kompetensi profesional, dan kompetensi sosial. Kompetensi dapat dipahami sebagai pengetahuan, keterampilan, dan nilai-nilai dasar yang direfleksikan dalam kebiasaan berfikir dan bertindak (Rochman \& Gunawan, 2011)

Kompetensi merupakan perilaku rasional untuk mencapai tujuan yang dipersyaratkan sesuai dengan kondisi yang dipersyaratkan. Kompetensi guru merupakan kemampuan seorang guru yang harus dimiliki dalam melaksanakan kewajibannya secara bertanggung jawab (Nurdin \& Bakar, 2011). Kompetensi pendidik/guru sangat diperlukan dalam menjalankan fungsi profesi. Profesi menuntut kemampuan dalam membuat keputusan yang tepat dan dalam membuat kebijaksanaan yang tepat. Kompetensi guru sangat diperlukan untuk mengembangkan dan mendemonstrasikan perilaku pendidikan, tidak hanya mempelajari keterampilan dalam mengajar, namun merupakan penggabungan dan pengaplikasian suatu keterampilan dan pengetahuan dalam bentuk nyata (Mulyasa, 2013, p. 31).

Kompetensi pedagogik merupakan kemampuan dalam mengelola pembelajaran peserta didik. Kompetensi kepribadian, merupakan kemapuan yang mantap, stabil, arif dan bijaksana serta menjadi teladan bagi peserta didik. 
Kompetensi sosial merupakan kemampuan guru untuk berkomunikasi dan berinteraksi dengan peserta didik, sesama guru, orang tua/wali, serta masyarakat luas. Kompetensi profesional merupakan kemampuan guru dalam penguasaan materi pelajaran secara luas dan mendalam (Fathorrahman, 2017).

Kompetensi guru memiliki efek yang besar terhadap kualitas proses belajar mengajar karena kompetensi guru menentukan performa mereka dalam memfasilitasi siswa untuk berhasil dalam pembelajaran (Inayah et al., 2013). Apabila dilihat dari beberapa penelitian yang terkait dengan kompetensi guru, menunjukkan bahwa adanya pengaruh kompetensi guru terhadap hasil belajar siswa.

Tujuan dari penelitian ini adalah untuk mengetahui latar alamiah SMP IT Imam Bukhari, pelaksanaan manajemen tenaga pendidik, faktor penunjang serta faktor penghambat dalam pelaksanaan manajemen tenaga pendidik, serta untuk mengetahui hasil manajemen tenaga pendidik dalam meningkatkan kompetensi profesional.

\section{METODE}

Pada penelitian ini menggunakan pendekatan kualitatif, yakni menggambarkan dan mengungkapkan fakta yang ada, kemudian dijelaskan secara deskriptif dengan kata-kata atau uraian dan menggunakan metode deskriptif, yakni metode yang bertujuan untuk mendeskripsikan masalah yang sedang terjadi atau berlangsung secara rinci apa adanya. Langkah-langkah yang perlu dilakukan dalam penelitian ini yaitu menentukan pendekatan dan metode penelitian, menentukan jenis dan sumber data, menentukan teknik pengumpulan data, menentukan teknik analisis data, dan menentukan teknik uji absah data. Metode yang digunakan dalam penelitian ini yaitu metode deskriptif kualitatif. Metode penelitian kualitatif merupakan metode penelitian yang berlandaskan pada filsafat positivisme (Sugiyono, 2017), yaitu digunakan untuk meneliti kondisi objek yang alamiah, di mana peneliti berperan sebagai instrumen kunci, teknik pengumpulan data dilakukan dengan cara triangulasi, teknik analisis data bersifat induktif/kualitatif, dan hasil penelitian kualitatif menekankan kepada makna dari pada generalisasi.

\section{HASIL DAN PEMBAHASAN}

\section{Perencanaan Tenaga Pendidik di SMP IT Imam Bukhari}

Perencanaan tenaga pendidik di SMP IT Imam Bukhari diawali dengan analisis jabatan, idealnya dilakukan berdasarkan dua standar yaitu kualifikasi akademik dan kompetensi. Adapun kualifikasi akademik belum sepenuhnya melihat dari latar belakang pendidikan, maka dibuatlah cara mapping atau pemetaan. Pemetaan yang dimaksud adalah melihat dari berbagai aspek yaitu pertama, menganalisis jumlah tenaga pendidik yang ada. Kedua, melihat jumlah jam pelajaran yang dibutuhkan. Kemudian, melihat dari struktur kurikulum menghasilkan berapa jumlah jam pelajaran yang dibutuhkan, dan kemungkinan realisasi jumlah jam pelajaran yang dibutuhkan. Dari proses tersebut, kemudian dilakukan proses penyesuaian atau pencocokkan.

Setelah proses pemetaan selesai, maka dilanjutkan pada proses rekrutmen dan seleksi. Rekrutmen yang dilakukan oleh SMP IT Imam Bukhari ini melalui tiga jalur yaitu jalur terbuka, jalur rekomendasi dan pengabdian. Langkah- 
langkah yang perlu ditempuh pada tahap rekrutmen adalah administrasi, tes potensi akademik, micro teaching, dan wawancara.

Castetter yang dikutip oleh Jahari (2013) membuat suatu konsep berkaitan dengan perencanaan tenaga pendidik dan kependidikan yang tergabung dengan proses rekrutmen. Konsep tersebut menjelaskan bahwa perencanaan sumber daya manusia (SDM) dimulai dari analisa terhadap kebutuhan sumber daya manusia dalam sebuah organisasi. Untuk mendapatkan personel yang sesuai dengan kebutuhan, maka ada dua sumber dalam proses pengadaan tersebut, yaitu eksternal yang dilakukan dengan proses rekrutmen terbuka, dan internal yaitu mengoptimalkan sdm yang sudah ada (Jahari \& Syarbini, 2013).

Dari hasil penelitian di SMP IT Imam Bukhari pada proses perencanaan diawali dengan analisis kebutuhan, pada proses tersebut menganalisis SDM yang dibutuhkan dan kualifikasi seperti apa yang harus dipenuhi. Setelah proses analisis tersebut selesai, atau disebut juga proses mapping atau pemetaan dilanjutkan pada proses rekrutmen dan seleksi.

\section{Pengorganisasian Tenaga Pendidik}

Pada tahap pengorganisasian terjadi penyusunan dan pembentukan hubungan-hubungan kerja antar komponen kepengurusan struktur organisasi sehingga terwujud satu kesatuan usaha dalam mencapai tujuan yang telah ditetapkan. Pengorganisasian tenaga pendidik di SMP IT Imam Bukhari yaitu dengan cara memberikan tugas tambahan kepada pendidik seperti kepanitiaan, dan pembinaan lainnya. Pendistribusian tenaga pendidik lebih banyak dilakukan oleh yayasan.

Pengorganisasian merupakan suatu proses penentuan, pengelompokkan, dan pengaturan berbagai aktivitas yang diperlukan untuk mencapai tujuan, menempatkan orang-orang pada setiap aktivitas serta menyediakan alat-alat yang diperlukan, juga menetapkan wewenang untuk didelegasikan kepada setiap individu yang akan melaksanakan aktivitas tersebut (Hasibuan, 2013, p. 40).

Pada pelaksanaannya, pengorganisasian tenaga pendidik tidak terlepas dari proses perencanaan. Setelah perencanaan dilaksanakan, barulah pengorganisasian tenaga pendidik dapat dilakukan karena melihat kepada beberapa tenaga pendidik yang berhenti dan juga beberapa tenaga pendidik yang baru dan melihat kepada kualifikasi tenaga pendidik. Maka, hasil penelitian di SMP IT Imam Bukhari dalam proses pengorganisasian terjadi proses pengelompokkan orang-orang sesuai dengan kualifikasinya, menentukan kegiatan-kegiatan maupun alat. Pemberian tugas selain mengajar merupakan salah satu cara dalam proses pengorganisasian yang dilakukan di SMP IT Imam Bukhari.

\section{Penyusunan Staf}

Proses staffing pendidik di SMP IT Imam Bukhari belum sepenuhnya sesuai dengan latar belakang pendidikan. Proses staffing tersebut bisa di lihat sesuai atau tidaknya dari segi kualifikasi dan juga sertifikasi guru. Dapat dipresentasekan kurang lebih $70 \%$ hingga $80 \%$. Hal tersebut juga menjadi kendala di berbagai lembaga pendidikan. 
Penyusunan staf atau staffing dimulai dari yayasan yaitu ada ketua, sekertaris juga bendahara. Kemudian setelah pengurus yayasan, yaitu ada pelaksana harian. Pelaksana harian didalamnya meliputi direktur pendidikan, bagian SDM, bagian QA (Quaility Assurance), keuangan, laboratorium dan komputer. Setelah itu di unit masing-masing mempunyai struktur tersendiri seperti kepala sekolah, wakil kepala sekolah bidang kurikulum, tata usaha, keuangan dan lain sebagainya. Struktur di setiap unit selalu berkoordinasi dengan struktur yang ada di yayasan.

Penyusunan staf atau staffing merupakan suatu kegiatan dalam organisasi yang sangat penting karena berkaitan dengan penempatan orang dalam tugas dan kewajiban tertentu yang harus dilaksanakan. Dalam sebuah organisasi, perlu sekali untuk mengadakan pembagian tugas sebaik-baiknya dan juga memberikan wewenang yang tepat. Pada proses staffing atau penyusunan staf harus menempatkan orang yang tepat pada setiap posisi. Staffing merupakan kegiatan merekrut, memilih, mempromosikan, memindahkan serta pengunduran diri. Penyusunan staf atau staffing merupakan kegiatan yang tidak terlepas dari pengorganisasian (Athoillah, 2010, pp. 117-118).

Penyusunan staf atau staffing yang dilakukan di SMP IT Imam Bukhari sebelumnya ditentukan jenis pekerjaan dan jumlah yang dibutuhkan. Kemudian, melihat keahlian yang sesuai dengan posisi yang dibutuhkan. Deskripsi tugas dan tanggung jawab pun dibuat. Penyusunan staf di SMP IT Imam Bukhari berganti dari tahun ke tahunnya, karena setiap tahunnya SMP IT Imam Bukhari mendata ulang pendidik yang tetap mengajar ataupun memilih berhenti.

\section{Penggerakkan Tenaga Pendidik}

Penggerakkan tenaga pendidik di SMP IT Imam Bukhari dilakukan dengan cara pembinaan melalui program-program sekolah. Ada beberapa program sekolah untuk proses penggerakkan tenaga pendidik. Pertama, pembinaan spiritual atau berkaitan dengan kompetensi kepribadian. Pembinaan spiritual merupakan kajian mingguan yang dilaksanakan kurang lebih selama dua jam, dalam kajian ini biasanya dibahas mengenai buku-buku tentang pendidikan. Kedua, yaitu program halaqah Qur'an. Ketiga, yaitu program fiah qalilah. Program fiah qalilah merupakan wadah untuk bertukar fikiran atau disebut sharing berkaitan dengan pembelajaran maupun kajian keislaman. Keempat, yaitu program pelatihan yang berkaitan dengan kompetensi pedagogik dan kompetensi profesional. Pelatihan tersebut meliputi pelatihan administrasi, pelatihan manajerial, pelatihan media pembelajaran dan lain sebagainya. Kelima, yaitu program lomba inovasi. Lomba inovasi bertujuan agar pendidik dapat mengembangkan metode pembelajaran, memanfaatkan sumber belajar dan lain sebagainya.

Penggerakkan atau disebut juga actuating merupakan kegiatan menggerakkan dan mengusahakan agar pekerja atau pegawai melakukan tugas dan kewajibannya. Para pekerja melaksanakan pekerjaannya sesuai dengan keahlian dan proporsinya masing-masing terhadap tujuan yang telah ditetapkan dengan selalu berkomunikasi, hubungan sesama manusia yang baik, kepemimpinan yang efektif, memberikan motivasi, membuat perintah dan intruksi serta mengadakan supervisi (Athoillah, 2010, p. 116). 
Hasil penelitian di SMP IT Imam Bukhari dalam hal pembinaan pekerja, peningkatan mutu dan kualitas kerja yaitu pembinaan pendidik, dan peningkatan mutu dilakukan melalui beberapa program sekolah yang berdampak pada kualitas kerja pendidik. Program sekolah juga menjadi cara untuk membimbing dan mendorong pendidik agar kemampuannya meningkat dan lebih baik lagi. Penilaian dan evaluasi juga menjadi cara untuk mengetahui pengaruh program terhadap kualitas kinerja maupun mutu pendidik, juga menjadi acuan pendidik untuk lebih baik lagi.

\section{Pengawasan Tenaga Pendidik}

Pengawasan yang dilakukan oleh kepala sekolah yaitu, pertama melalui aspek kehadiran. Kehadiran akan terus di evaluasi baik manual maupun dari finger print. Hasil musyawarah, sekolah mempunyai rencana untuk membuat buku khusus tenaga pendidik dan kependidikan, yang mana buku tersebut berisi tentang catatan pribadi ataupun kinerja pendidik yang nantinya mempermudah proses evaluasi yang dilakukan oleh kepala sekolah. Namun, rencana tersebut masih diusahakan sampai saat ini, artinya belum terealisasikan. Program reward dan punishment juga menjadi salah satu cara dalam proses pengawasan.

Pengawasan didefinisikan sebagai suatu proses pemantauan yang terus menerus untuk menjamin terlaksananya perencanaan secara konsekuen baik yang bersifat materil maupun spiritual. Pengawasan harus berkaitan dengan tujuan dan kriteria yang digunakan dalam sistem pendidikan, pengawasan harus disesuaikan dengan sifat dan kebutuhan organisasi dan pengawasan hendaknya mengacu pada tindakan perbaikan dalam (Ramayulis dalam (Jahari \& Syarbini, 2013)).

Hasil penelitian di SMP IT Imam Bukhari dalam hal pengawasan diarahkan pada pembuatan RPP, absensi kehadiran, penguasaan materi, penggunaan metode dan media dalam mengajar. Pengawasan ini bertujuan pada tindakan perbaikan ketika terdapat kekurangan atau ketidak sesuaian yang ditemukan di lapangan.

\section{SIMPULAN}

Pengorganisasian tenaga pendidik di SMP IT Imam Bukhari dilaksanakan setelah proses seleksi dan penempatan tenaga pendidik dan disesuaikan dengan analisis kebutuhan. Pengorganisasian tenaga pendidik yaitu melalui penugasan tenaga pendidik diluar kewajibannya mengajar. Adapun pendistribusian pendidik lebih banyak dilakukan oleh bagian SDM dari pihak yayasan. Penyusunan staf di SMP IT Imam Bukhari dilakukan sesuai dengan kebutuhan dan berdasarkan pada standar pengelolaan sekolah. Namun juga dilakukan perampingan sesuai dengan kebutuhan dan sumber yang ada. Dalam penyusunan tersebut melihat kepada kualifikasi dan kompetensi yang dimiliki tenaga pendidik. Penggerakkan pendidik dilakukan dengan cara pembinaan melalui program-program sekolah yang telah dibuat. Program-program tersebut yaitu pembinaan spiritual yang berkaitan dengan kompetensi kepribadian pendidik, program Halaqah Qur'an, program fiah qalilah atau program untuk sharing atau bertukar gagasan dan juga membahas proses pembelajaran, program pelatihan yang berkaitan dengan kompetensi pedagogik dan kompetensi profesional, dan program lomba inovasi pembelajaran. Pengawasan 
dilakukan oleh kepala sekolah melalui kehadiran tenaga pendidik baik secara manual maupun kehadiran dari finger print. Pengawasan juga dilakukan dengan evaluasi dan observasi kepala sekolah pada proses belajar mengajar.

\section{REFERENSI}

Athoillah, A. (2010). Dasar-Dasar Manajemen. Pustaka Setia.

Badrudin, B. (2015). Dasar-Dasar Manajemen. Alfabeta.

Basri, H. (2009). Filsafat Pendidikan Islam. Pustaka Setia.

Fathorrahman, F. (2017). Kompetensi Pedagogik, Profesional, Kepribadian dan Kompetensi Sosial Dosen. Akademika: Jurnal Manajemen, Akuntansi Dan Bisnis, 15(1), 1-6. https://doi.org/10.51881/jam.v15i1.67

Fitriani, C., Murniati, A., \& Usman, N. (2017). Kompetensi Profesional Guru Dalam Pengelolaan Pembelajaran di MTs Muhammadiyah Banda Aceh. Jurnal Administrasi Pendidikan : Program Pascasarjana Unsyiah, 5(2), 8895. http://jurnal.unsyiah.ac.id/JAP/article/view/8246

Hasibuan, M. S. P. (2013). Manajemen: Dasar, Pengertian, dan Masalah. Bumi Aksara.

Inayah, R., Martono, T., \& Sawiji, H. (2013). Pengaruh Kompetensi Guru, Motivasi Belajar Siswa, dan Fasilitas Belajar Terhadap Prestasi Belajar Mata Pelajaran Ekonomi Pada Siswa Kelas XI IPS SMA Negeri 1 Lasem Jawa Tengah Tahun Pelajaran 2011/2012. Jurnal Pendidikan Insan Mandiri, 2(1). https://doi.org/10.20961/iman.v2i1.19638

Jahari, J., \& Syarbini, A. (2013). Manajemen Madrasah: Teori, Strategi, dan Implementasi. Alfabeta.

Mulyasa, E. (2013). Standar Kompetensi dan Stratifikasi Guru. PT Remaja Rosdakarya.

Nurdin, D., \& Bakar, A. (2011). Manajemen Sumber Daya Pendidikan. PT Sarana Panca Karya Nusa.

Rochman, C., \& Gunawan, H. (2011). Pengembangan Kompetensi Kepribadian Guru (Menjadi Pendidik yang Dicintai dan Diteladani Siswa). Nuansa Cendekia.

Sagala, S. (2012). Administrasi Pendidikan Kontemporer. Alfabeta.

Sugiyono. (2017). Metode Penelitian Kuantitatif, Kualitatif dan R\&D. Alfabeta.

Susanti, S. (2014). Meningkatkan Efektivitas Pendidikan Nonformal Dalam Pengembangan Kualitas Sumber Daya Manusia. Jurnal Handayani, 1(2), 9-19. https://doi.org/10.24114/jh.v1i2.1255

Syarbini, A. (2012). Buku Pintar Pendidikan Karakter (Panduan Lengkap Mendidik Karakter Anak di Sekolah, Madrasah, dan Rumah). as@-prima. Wahyudi, I. (2012). Pengembangan Pendidikan (Strategi Inovatif dan Kreatif Dalam Mengelola Pendidikan Secara Komprehensif). PT Prestasi. 